\title{
Meaning and Values in the Consumption of Fashion by Men
}

\author{
Ana Paula Celso de Miranda ${ }^{1}$, Eduardo Jorge Carvalho Maciel $^{2} \&$ Olga Maria Coutinho Pepece ${ }^{3}$ \\ ${ }^{1}$ Núcleo de Design e Comunicação, Universidade Federal de Pernambuco, Caruaru, Brazil \\ ${ }^{2}$ Faculdade SENAC Pernambuco, Recife, Brazil \\ ${ }^{3}$ Programa de Pós Graduação em Administração, Universidade Estadual de Maringá, Maringá, Brazil \\ Correspondence: Ana Paula Celso de Miranda, Núcleo de Design e Comunicação, Universidade Federal de \\ Pernambuco, Caruaru, Brazil. E-mail: apcm7@hotmail.com
}

Received: October 11, 2016 Accepted: November 8, 2016 Online Published: November 28, 2016

doi:10.5539/ijms.v8n6p97 URL: http://dx.doi.org/10.5539/ijms.v8n6p97

\begin{abstract}
The objective of this study was to analyze the discourse on fashion consumption and fashion brands by male inhabitants of Caruaru city, State of Pernambuco, Northeastern Brazil. The findings include the way men understand fashion consumption and the values that direct them to buy fashion brands. These men see fashion consumption as the act of buying and consuming fashion brands in order to acquire various levels of status and express their values. When their discourse leaves the domain of fashion, the act of dressing becomes functional, an expression of personality and occupation. By doing this, it becomes part of the male universe. The following symbolic associations were identified, which were related to the motivational types of values proposed by Tamayo and Schwartz: Self-Realization/Self-Esteem, Belonging/Compliance, Contemporaneity/Hedonism, Rationality/Confidence, Distinction/Self-Determination, and Ostentation/Social Power. It may be concluded that the consumption of fashion and fashion brands by the men in the studied context are directly related to the social group they belong to, or would like to belong to (aspiring group). Regarding the group they belong to, the participating men, while consuming fashion and fashion brands, choose items that reflect the values of their group in order to feel part of it. However, insatiable desires, inherent to all human beings, do not allow that the Caruaru men are satisfied with the feeling of belonging to a group only, driving them to seek in the consumption of fashion and fashion brands those items that will make them feel valued and recognized as being unique.
\end{abstract}

Keywords: menswear, symbolic consumption, values

\section{Introduction}

Marketing may be defined as a business philosophy, or way of thinking, that a company has from the perspective of consumers, or potential consumers (Eassey, 1995), which explains the importance of understanding consumer behavior as a starting point for all marketing actions. This understanding passes by the attribution of meaning to products and the symbolic construction of brands (Desmond 2003), the cultural significance of products (McCracken, 1986), the semiotics of consumption (Holman, 1981; Mick, 1986), products as tools for self-expression (Belk, 1988; Prentice, 1987), and impression formation based on possessions (Belk, 1978; Dittmar \& Pepper, 1994; Gosling et al., 2002). Therefore, the marketing professional must follow trends, i.e., the changes that are occurring in the market and are being incorporated into consumer behavior.

Trend, or fad, can be defined by its combined set of variants as the greatest expression of the dominant taste, with a limited period of validity (Miranda \& Monçores, 2013). Trends manipulate the consumer, a person waiting for the new, to accept their constant changes to stay "up-to-date" or "be fashionable". The "be fashionable" idea has a strong sense of symbolic expression, as it depends on the recognition by others of what an individual chooses to wear to demonstrate that he is "fashionable". This recognition is often made possible through the use of brands that are widely known in the market.

Interestingly, changes in trend occur so that individuals are kept exactly where they are: in synchrony with the present time. Trends, permeated by change, retrieve the Renaissance idea of fashion, marking a particular period of time in an increasingly diffuse space, as it seeks to extend its tentacles until it is replaced by new trends, establishing fashion life cycles (Garcia \& Miranda, 2005).

Fashion (Note 1) is the phenomenon that better demonstrate the capacity of/need for change in society, which is 
reflected on consumption processes. Fashion essentially involves change, defined by asuccession of trends and quirks in a short period of time; It is a planned obsolescence process (Note 2) (Eassey, 1995).

By analyzing fashion phenomena we can identify the wants and desires of a particular social group (Note 3) at a given time and space.

To understand the phenomenon of fashion analyzed in this study, it is important to realise that most of society members firstly identify fashion as a field reserved for customs and adornments. However, fashion is not restricted to garments only. Architecture, the automotive industry, interior design, first names, business management, to mention a few, are all affected by fashion.

This process, regardless of its purpose, has two unique aspects: the quest for individuality, and the need for social integration. Hence, fashion can be understood as a psychosocial phenomenon. The detailed analysis of the social and psychological significance of clothing fashion can indicate the differences in behavior among social groups and help to shed light on the main influences that form consumer motivations (Calefato, 2004). Therefore, to understand the fashion code, basic principles of psychology, sociology, anthropology, and semiotics communication are required. Each of these sciences separately analyze, from a particular point of view, the fashion consumption process. In possession of the various viewpoints of fashion behavior, marketing strategies may be then developed to address fashion consumption needs.

The object of study here is fashion and fashion brands in connection with the esthetic products (clothing, accessories, jewelry) consumed by men. The choice of the theme was based on the affinity of the authors with the field; among the important factors that determine the choice of a theme are the personal preferences and judgments of value; by being aware of this fact, the bias that could permeate the study is minimized (Selltiz et al, 1987). Additionally, this study is also justified by the promising growth observed in the men's fashion market (Oshyma, 2014). According to the MARKETLINE research institute (Oshyma, 2014), men's fashion market is estimated to achieve a US\$ 5 billion growth in the period between 2013 and 2017. In regards to the consumption of menswear and its relationship with fashion brands, $61 \%$ of the Brazilian men belonging to the social economic lower middle-classes $\mathrm{C}$ and $\mathrm{D}$ disclosed a preference for well-known brands of clothing (SEBRAE, 2015). This study intends to make an academic and practical contribution by presenting those factors found in the person-object relationship that encourage consumers not to purchase the object itself, but their narrative.

\section{Consumption, Fashion and Gender}

With the arrival of the modern age, a period of great transformation experienced by western society between the $16^{\text {th }}$ and $17^{\text {th }}$ century, humanity underwent major social historical changes. The driving force behind these changes was the new way of understanding and living consumption. McCracken (2003) concluded that, with the industrial revolution, western societies began to consider these changes not only as a possibility to have access to products before destined to a few, but as new way of being based on having. Changes in consumption values and meanings were built by groups or cultures that have validated and maintained them present and alive in time and space.

There are several disciplines that study consumption and, within their specificities, attempt to understand and justify the reasons for consumption habits: since the perspective of the neoclassical economics, which investigates the balance between cost and utility, passing by sociology and its point of view on the relations of social distinction, until the anthropological vision on the formation of cultural patterns (Barbosa, 2006). If the desire to consume is fed back by culturally constructed desires, we have in the consumption of fashion one of the strongest cultural representations, due to its dynamics, access and massification of values and meanings (McCracken, 2003). This integration initially served to identify classes and castes. Later, other social and cultural groups and subgroups made use of fashion status codes to build their messages through the colors, textures and modelings displayed by their garments (Blumer, 1969).

To understand the messages and values of the fashion visual discourse, it is necessary to dive into the cultures that built these messages; only then one can read not only the lines but also between the lines (Lurie, 1997). This understanding becomes more complex as we deepen our gaze into issues of gender and groups, in which the new values and meanings of a culture are shaped to people's desires, leading to cultural subgroups (Solomon \& Rabolt, 2004).

With the arrival of the $20^{\text {th }}$ century, according to Kacen (2000), to study consumption distinctions based on gender loses strength, while issues connected to a particular culture, and its subcultures,becomes the focus of analysis. The study of consumption now looks into the culture of appearance, of social integration; the reality of being - what I want to be/how I want to be perceived — and the virtual reality of what I am, or what I interpret 
based on the answer I get from my universe. Still from the same viewpoint, gender, as directly associated with male or female, has its rules built on the social behavior patterns and symbols of the place an individual lives. Thus, gender identity should not be understood as a boy x girl label attached only to the genitalia. Gender should be interpreted based on the analysis of where this boy and/or girl is, and where we are (Harris, 1998). This perception of gender helps us to understand consumption as an active cultural process; consumption is seen as a material way to build identities: we become what we consume (Miller, 1997), regardless of being a boy or a girl.

Focused on marketing, Kacen (2000) shows us that, historically, fashion has focused on the female gender. While the study of consumption has been more and more focused on women, product development has been seen as a male role. Women have clearly shown the greatest changes in gender roles (Kacen, 2000). In the past, women was typically associated with the consumption of household items. Nowadays, the new woman is seen according to her individual/personal consumption and the activities she performs other than in the home. Although less dramatic, the perception of men have also been undergoing changes. Men, previously associated with consumer issues such as home/family/provider, are now being seen as "individuals". Values other than family's start to be representative (Kacen, 2000). Despite the fact that men have a more practical approach to purchasing than women (Magalhães, Souza, \& Duarte, 2001), it is important to notice that there is a new way of seeing gender, not just as a set of feminine and masculine characteristics, but a universe of elements in a given time and space, and its perpetuation in the analyzed culture (Kacen, 2000).

Although the concept of fashion consumption, as we know it today, is focused on women, dressing concerns have always been present among men (Magalhães, Souza, \& Duarte, 2001). The authors illustrate this by reminding us that the indigenous men of Brazil valued their ornaments as much as the Portuguese aristocrats were rather concerned with the appearance of their garments.

\section{Consumer Culture}

The concern with one's appearance is related to the types of values that matter to a particular group of people. Tamayo and Schwartz (1993, p.330), when talking about values, point out that these represent a "force that takes the individual to seek, often throughout life, the achievement of goals". According to the authors, the values are expressed through motivational types, which in the Brazilian culture are divided into nine types with different goals: 01) Hedonism: pleasure and sensual gratification; 02) Self-Realization: personal success obtained by demonstrating self-competence that leads to social recognition; 03) Social Power: social status, prestige and control over people and resources; 04) Self-Determination: independence of thought, action, option; 05) Compliance: control of impulses and behavior in accordance with social expectations; 06) Kindness: concern for the welfare of people who are close; 07) Safety: the integrity of self and of the people and groups identified with; 08) Tradition: respect and acceptance of the ideals and customs of one's society; and 09) Philanthropy: understanding and acceptance of others, and concern for the well-being of all.

According to Sartre (1997), "have", "do" and "be" are the cardinal categories of human reality and, in them, all behaviors of men or women are classified. The property of things serve as symbol of identification, i.e., having means being. Thus, the members of a society can communicate among themselves through this classification process. In the studied universe, that is, the State of Pernambuco (a state located in the Northeast of Brazil), the local cultural characteristics are important collaborative factors for the consumption habits by men; especially in the city of Caruaru (3rd largest clothes manufacturing cluster in Brazil), whose economy is based on the production of clothing and fashion. In this clothing manufacturing region were identified 123.000 production units [SEBRAE, 2013] distributed in the 10 cities that make up this cluster. As the largest city polo, Caruaru is considered reference both technology and trend in fashion production in the region accounting for $70 \%$ of this production. Another relevant fact for this study is as it has been working the product adaptation process of this cluster with your target audience, pointing out that $59.9 \%$ of these companies has its own fashion creation.

According to Belk (2004) the consumer culture exists based on four conditions:

1. A substantial proportion of the population consumes at levels above subsistence.

2. Exchanges dominate the production of consumer goods.

3. Consumption is acceptable as an appropriate and desirable activity.

4. People judge others and themselves in terms of their consumer lifestyle.

Focusing on the traditional universe of Pernambuco during the sugarcane golden period ( $16^{\text {th }}$ and $17^{\text {th }}$ century), the need for consumption of meanings by men is noticed when we read in the work of Freyre (1987) that:

"In societies called bourgeois, the way married women present themselves in public is a means of their husbands 
asserting their success and position in society. Therefore, it is necessary that the dresses of wives and daughters vary from less to more exuberantly expensive and are adorned as an expression either of high status constancy, increased prosperity, economic, social or political rising, or the distinguished positions occupied by their husbands and fathers" (Freyre, 1987, p.31).

Moreover, also according to the author, fashion is imposed; "[...] it is the pressure from the collective consensus on personal tastes" (Freyre, 1987, p. 18). Although a consensus between individual taste and collective pressure is possible, differences do exist, and function as drivers of fashion changes. The imposition of the general over the individual is the basis on which fashion is established. The pressure takes place based on individuals believing that being "out of fashion" is "[...] social condemnation of their position in the society or culture they are part of" (op.cit., p. 19).

We are obviously talking about four centuries ago, but this conservatism is still present in Pernambucan society today, building social-theatrical roles contradictory to our times, as seen in the work of Miranda and Maciel (2007). According to the authors, constructed values on status symbols are permanent and valued in this universe. Thus, men symbolically constituted in this society tend to see fashion as an indicator of social status.

Still in the Brazilian context, some studies highlighting the issue have been conducted. Among them, there is the study by Davidovitchand e Da Silva (2010), in which the male perception of symbolic values has a significant influence on their involvement with clothing. The authors also highlight that different degrees of involvement may take place in different markets. Thus, creation and marketing professionals should focus their attention on the desired target audience. Coutinho and Portinari (2014) estimate that the way fashion is seen is directly linked with self-esteem and the construction of identity. For the authors, the offer and the variety of clothes seen today stimulate the higher consumption of fashion by men but, at the same time, it is clear that their choices also reinforce the symbolism and representations of the universe they live.

\section{Research Method}

According Mattar (1994, p.61), "scientific research is an activity aimed at solving problems". The research problem to be analysed in this study is the following:

\section{"What are the meanings attributed to fashion consumption and fashion brands by men in Caruaru?"}

Clothing manufacturing is the economic lifeline of the city of Caruaru. Therefore, the objective of this study was to analyze how fashion significance is built by men in an environment economically dependent on the fashion industry. Moreover, the study also analyzes, from a symbolic perspective, fashion brands as objects and symbols of male consumption that help them to communicate socially.

Richardson (1999) presents a clear justification for the choice of the interpretive paradigm. For the author, the qualitative approach to a problem is the most suitable for the study of social phenomena. This is a line of study that enables that complex or strictly private objects may be analyzed and understood. "Studies employing a qualitative methodology can describe the complexity of a given problem, analyze the interaction of certain variables, and understand and classify the dynamic processes experienced by a social group" (Richardson, op. Cit., P. 80).

Thus, this study was conducted from a cultural perspective, following a qualitative research approach making use of in depth interviews with the following sample of randomly selected men (Table 1):

Subjects: 25 men aged between 18 and 47 years old.

Scope: $\quad$ The city of Caruaru - South Agreste of Pernambuco State, Brazil. 
Table 1. Profile of the 25 study participants

\begin{tabular}{lll}
\hline AGE & SOCIAL CLASS & OCCUPATION \\
\hline 18 & A & Student \\
\hline 19 & B & Student \\
\hline & D & Student \\
20 & B & Businessman \\
& B & Freelancer \\
& B & Student \\
\hline & B & Student \\
21 & B & Businessman \\
& B & Freelancer \\
& B & Student \\
\hline 22 & B & Student \\
\hline & B & Student \\
23 & B & Student \\
& B & Freelancer \\
\hline 24 & A & Businessman \\
\hline 25 & B & Student \\
\hline 26 & B & Student \\
\hline & B & Freelancer \\
\hline 27 & B & Student \\
\hline 32 & B & Businessman \\
\hline 47 & B & Freelancer \\
\hline & & Freelancer \\
\hline & B & Freelancer \\
\hline & Freelancer \\
\hline & Businessman \\
\hline
\end{tabular}

Source: Field survey.

\section{Discussion and Analysis of Results}

Findings include how participating men understand fashion consumption; the symbolic and functional attributes and values that motivate them to purchase fashion and fashion brands. The meaning given to the word fashion, and the narrative of the men on their dynamic fashion consumption, take the study into gender issues. This permits to amplify the understanding of the symbolic construction from a different perspective: the perception of fashion as belonging to the female universe, highly linked to femininity and, therefore, the acquisition of meanings such as "futile", "irrelevant" and "useless", which is not consistent with male symbolic issues. In contrast, the symbolic universe of men is seen as an important aspect of life, demonstrating cultural values and beliefs attached to male items as being good and important (men's things), while female items are seen as being bad and useless (women's things). Therefore, the research identifies categories that explain the aversion to the word fashion, and categories related to the understanding of "men's things". According to the interviews, feeling good, innovation, style, individuality, aesthetics and quality are relevant categories to fashion consumption by the participating men. These men see fashion consumption as the act of buying and consuming fashion brands in order to acquire various levels of status and express their values. When their discourse leaves the domain of fashion, the act of dressing becomes functional, an expression of personality and occupation. By doing this, it becomes part of the male universe.

It is common to "interpret" someone by the way they dress. Signs, present in the clothing of those who are being observed, allow the observer to infer on various issues such as gender, social class, occupation, personality, among others. When groups and subcultures are analyzed based on their garments, one must be aware of the values underlying the aesthetics of those observed. Values are built and shaped by historical, economic, social, and cultural events, and have clear-or disguised - effects on the waya subculture or group, in this case men, dresses.

Based on the results of this study, six categories were built based on the data collected, which were related to the motivational types described by Tamayo and Schwartz (1993). These categories refer to men's values and meanings attributed to fashion consumption (Table 2). 
Table 2. Study results

\begin{tabular}{|c|c|c|c|}
\hline Category & $\begin{array}{l}\text { Interview } \\
\text { Code }\end{array}$ & Question & Evidence \\
\hline Feeling good & Int. 01 & What's fashion for you? & $\begin{array}{l}\text { "Fashion is ... Fashion is getting dressed up, fashion is conforming to the } \\
\text { trend, is..is ... From that time, always to change your clothing to a very } \\
\text { current style". }\end{array}$ \\
\hline \multirow[t]{3}{*}{ Belonging } & Int. 04 & $\begin{array}{l}\text { Who influences you in } \\
\text { the adoption of a fashion } \\
\text { brand? }\end{array}$ & $\begin{array}{l}\text { "People that I live with. My wife, my family, my friends, where I go, } \\
\text { according to the people I meet, according to hum ... hum ... the } \\
\text { suggestions, or sometimes a compliment on the clothes we are wearing, we } \\
\text { learn. We try to dress in accordance with... with the environment so that we } \\
\text { also feel good". }\end{array}$ \\
\hline & int. 20 & $\begin{array}{l}\text { What are the fashion } \\
\text { brands that arouse your } \\
\text { desire to consume? } \\
\text { Why? }\end{array}$ & $\begin{array}{l}\text { "The brands everyone thinks they like, the Italian brands, European } \\
\text { brands. Armani*, Luis (Louis Vuitton)*,in short the whole group". }\end{array}$ \\
\hline & Int. 21 & $\begin{array}{l}\text { What does it mean to be } \\
\text { fashionable for you? }\end{array}$ & $\begin{array}{l}\text { "Where you arrive, you arrive, you have to be dressed according to the } \\
\text { place and the people who are there". }\end{array}$ \\
\hline \multirow[t]{2}{*}{ Contemporaneity } & Int. 12 & $\begin{array}{l}\text { What does it mean to be } \\
\text { fashionable for you? }\end{array}$ & $\begin{array}{l}\text { "I think 'Being fashionable' is to follow a trend. That may be dictated by } \\
\text { others or simply personal". }\end{array}$ \\
\hline & Int. 04 & $\begin{array}{l}\text { What does it mean to be } \\
\text { fashionable for you? }\end{array}$ & $\begin{array}{l}\text { "It is the style of clothing, the language of a time, a place, for a group of } \\
\text { people." }\end{array}$ \\
\hline Rationality & Int. 21 & $\begin{array}{l}\text { What does it mean to be } \\
\text { fashionable for you? }\end{array}$ & $\begin{array}{l}\text { "Being fashionable is ... besides from wearing what is 'hype', the trend, } \\
\text { being fashionable is to feel well within the trend. It does not mean I'm } \\
\text { going to wear everything that is in evidence, but being fashionable is to be } \\
\text { inside, be aware of what one can and can not wear as well as possible, } \\
\text { with a personal trait. Because I think fashion, in addition to showing that } \\
\text { today there is this or that tendency, in the future there will be another } \\
\text { trend, and then it will go back ... all of this is fashion. But ... I think that } \\
\text { being fashionable is to synthesize everything into your personal } \\
\text { characteristic, which reflects what you are and what you enjoy wearing." }\end{array}$ \\
\hline \multirow[t]{3}{*}{ Distinction } & Int. 15 & $\begin{array}{l}\text { What you want to } \\
\text { express to others when } \\
\text { consuming a fashion } \\
\text { brand? }\end{array}$ & "Joy!" \\
\hline & Int. 10 & $\begin{array}{l}\text { What do you think } \\
\text { makes a fashion brand } \\
\text { successful? }\end{array}$ & $\begin{array}{l}\text { "I think it's the question related to the usefulness of pieces; advertising } \\
\text { also influences, for example, an actor that wears that outfit. Alessandra } \\
\text { Ambrosia*** wore a Colcci*, you get much more motivated to buy than } \\
\text { any advertising with anunknown person. It is different to have Ashton } \\
\text { Kutcher***, I look and I want to buy the jacket he is wearing. Advertising } \\
\text { greatly influences the amount of items ... it is this thing of being more } \\
\text { exclusive. I wish that there aren't enough pieces for everyone, and that } \\
\text { there aren't many pieces". }\end{array}$ \\
\hline & Int. 05 & $\begin{array}{l}\text { What do you think } \\
\text { makes a fashion brand } \\
\text { successful? }\end{array}$ & $\begin{array}{l}\text { "It would be ... first a question of marketing. I think the image of the brand } \\
\text { brings values too, it is ... in short, to show people who have something to } \\
\text { do with the reality of consumers and also the question of ... price, } \\
\text { accessibility to the product." }\end{array}$ \\
\hline Ostentation & Int. 18 & $\begin{array}{l}\text { What are the fashion } \\
\text { brands that arouse your } \\
\text { desire to consume? } \\
\text { Why? }\end{array}$ & $\begin{array}{l}\text { "Apple**, Calvin Klein**, I think because, for me they show status ... yes, } \\
\text { yes ... status." }\end{array}$ \\
\hline
\end{tabular}

Source: Field research.

Notes. ${ }^{*}$ Brands associated with the higher social classes.

** Brands associated with modernity.

*** TV and cinema celebrities.

\section{Final Considerations}

By analyzing the discourse of the participating men, meanings and values attributed to fashion consumption were identified. After that, these meanings and values were related to the motivational types of the Brazilian 
culture described by Tamayo and Schwartz (1993). This permitted to observe the existence of a close relationship between some of the motivational types and the values and meanings attributed to fashion consumption, reflecting these men culture (Table 3 )

Table 3. Motivational types and fashion values of participating men

\begin{tabular}{|c|c|}
\hline Motivational types & Symbolic association and fashion values in the universe of the participating men \\
\hline Motivational type $01-$ Hedonism & Contemporaneity — values related to the present and product innovation. \\
\hline Motivational type 02 - Self-Realization & $\begin{array}{l}\text { Feel good-values related to clothing improving self-image obtained by demonstrating } \\
\text { self-competence that leads to social recognition }\end{array}$ \\
\hline Motivational type 03 - Social Power & Ostentation — values related to the high price of products for purposes of social status. \\
\hline Motivational type $04-$ Self-Determination & $\begin{array}{l}\text { Distinction-values related to an individual standing out of their group or in the group } \\
\text { they aspire. }\end{array}$ \\
\hline Motivational type $05-$ Compliance & Belonging — values related to the desire to be part of a group or social class. \\
\hline Motivational type $07-$ Safety & Rationality-values related to clothing material characteristics and wearability. \\
\hline
\end{tabular}

Source: Field research.

It may be concluded that the consumption of fashion and fashion brands by the men in the studied context are directly related to the social group they belong to, or would like to belong to (aspiring group). Regarding the group they belong to, the participating men, while consuming fashion and fashion brands, choose items that reflect the values of their group in order to feel part of it. However, insatiable desires, inherent to all human beings, do not allow that the Caruaru men are satisfied with the feeling of belonging to a group only, driving them to seek in the consumption of fashion and fashion brands those items that will make them feel valued and recognized as being unique.

As to the question of functionality related to fashion consumption and fashion brands, it emerges as a rational discourse that extols the clothing materials characteristics and wearability, values associated with the search for safety (to purchase the right item), that is, to properly allocate resources on this type of consumption.

It is hoped that the findings of this study may contribute to further the knowledge on the relationships between meaning forming processes and consumption values, and how they affect consumers, particularly the consumption of fashion by men, so that strategies to improve the dialogue between fashion brands and the male audience may be developed. In the academic field, future research may make use of the suggested categories, relating them to other groups of men in different geographical areas, with generalizing purposes.

\section{References}

Belk, R. (1978). Assessing the effects of visible consumption on impression formation. Advances in Consumer Research, 5, 39-47.

Belk, R. (1988). Possessions and the extended self. Journal of Consumer Research, 15(September). https:/doi.org/10.1086/209154

Belk, R. (2004). The Human Consequences of Consumer Culture. In K. M. Ekstrom \& H. Brembeck (Eds.), Elusive Consumption. Oxford: Berg.

Coutinho, T., \& Portinari, D. (2014). O Discurso da Moda na Construção do Ideal de "Novo Homem". $10^{\circ}$ Colóquio de Moda, Caxias do Sul/RS.

Davidovitch, L., \& Da Silva, J. F. (2010). Algumas implicações da Percepção dos Valores das Roupas: Gênero Masculino em Foco, São Paulo, SP. RAM-Revista de Administração Mackenzie, 11(1). São Paulo, SP • JAN./FEV. https:/doi.org/10.1590/S1678-69712010000100007

de Miranda, A. P. C., \& Maciel, E. J. C. (2007). Reflexões sobre possíveis relações entre as modas da sociedade açucareira e o consume sócio-teatral-reproduces do estilo de vida casa grande e senzala? In: III Colóquio de Moda, Belo Horizonte. Annuals from III Colóquio de Moda, Belo Horizonte/MG.

de Miranda, A. P., \& Monçores, A. (2013). Esse tal de Espírito do Tempo... Revista Dobras, 14. São Paulo: Estação das Letras e Cores.

Desmond, J. (2003). Consuming behaviour. Nova York: Palgrave Macmillan.

Eassey, M. (1995). Fashion Marketing. United Kingdom: Blackwell Science.

Freyre, G. (1987). Modos de homem e modas de mulher. Rio de Janeiro, Record. 
Gosling, S. D., Ko, S. J., Morris, M. E., \& Mannarelli, T. (2002). A room with a cue: personality judgements based on offices and bedrooms. Journal of Consumer Research, 24(3), 379-389. https:/doi.org/10.1037/0022-3514.82.3.379

Holman, R. H. (1981). Product use as communication: a fresh appraisal of a venerable topic. In B. M. Enis \& K. J. Roering (Eds.), Review of Marketing (vol. 106, p. 19). Chicago, IL: American Marketing Association.

Kacen, J. J. (2000). Girrrl power and boyyy nature: the past, present, and paradisal future of consumer gender identity. Marketing Intelligence and Planning, 18, 6-7. https:/doi.org/10.1108/02634500010348932

Magalhães, C., de Souza, C., \& Duarte, L. (2001). Consumidor masculino em alta: Despesas com aparência pessoal não devem passar de $10 \%$ do orçamento. Jornal do Comercio do Rio de Janeiro, Rio de Janeiro, 2001. Retrieved from http://www.acomp.com.br/JCommercio28290101.htm

McCracken, G. (1986). Culture and consumption: A theoretical account of the structure and movement of the cultural meaning of consumer goods. Journal of Consumer Research, pp. 71-84. https:/doi.org/10.1086/209048

McCracken, G. (2003). Cultura e consumo: novas abordagens ao caráter simbólico dos bens e das atividades de consumo. Rio de Janeiro: Mauad.

Mick, D. G. (1986). Consumer research and semiotics: exploring the morphology of signs, symbols, and significance. Journal of Consumer Research, 13(September). https:/doi.org/10.1086/209060

Oshyama, F. Y. (2014). Abaixo o sexismo na moda: a vez dos homens chegou. Passou da hora de parar com a zombaria a respeito de homens que gostam de moda. Chega do "tem para homem?" Epoca - Globo.com, 07/07/2014. Retrieved from http://epoca.globo.com/colunas-e-blogs/Flavia-Yuri-Oshima/noticia/2014/07/abaixo-o-bsexismo-na-modabvez-dos-homens-chegou.html

Sartre. J. (1997). O ser e o nada-Ensaio de ontologia fenomenológica. Petrópolis, RJ: Vozes.

Sebrae (2015). Eles estão consumindo mais moda. Moda SEBRAE. 2015. Retrieved from $\mathrm{http}: / / \mathrm{www}$.sebraemercados.com.br/eles-estao-consumindo-mais-moda

Tamayo, A., \& Schwartz, S. H. (1993). Estrutura motivacional dos valores humanos. Psic.: Teor. e Pesq., Brasilia, 9(2), 329-348.

\section{Notes}

Note 1. Fashion as a process is when new styles are created and released for public consumption and become popularly accepted by this public. Thus, fashion is a behavior that is temporarily adopted by some of the members of a social group, socially appropriate for the time and the situation (Sproles, 1979). As an object, fashion is a style accepted by a large group of people for a certain time and space (Kaiser, 1998).

Note 2. The ideological process that immerses the self-perception of consumers into the meanings of cultural and social ideals that promote a perpetual state of dissatisfaction with the lifestyle and the current physical appearance (Thompson \& Haytko, 1997).

Note 3. According Greimas (1976), the term "group" refers to a set of individual elements, taken as a whole as a result of what each element possesses and the common features to the group; group elements must be homogeneous to be understood as a whole.

\section{Copyrights}

Copyright for this article is retained by the author, with first publication rights granted to the journal.

This is an open-access article distributed under the terms and conditions of the Creative Commons Attribution license (http://creativecommons.org/licenses/by/4.0/). 